\title{
Nitrate leaching, water-use efficiency and yield of corn with different irrigation and nitrogen management systems in coastal plains, USA
}

\author{
G. C. Sigua, K. C. Stone, P. J. Bauer \& A. S. Szogi \\ Coastal Plains Soil, Water and Plant Research Center, \\ United States Department of Agriculture, Agricultural Research Services, \\ Coastal Plains Soils, Water and Plant Research Center, USA
}

\begin{abstract}
Irrigation management for corn (Zea mays L.) production on the typical low water holding capacity soil of the southeastern USA needs to be improved to increase irrigation efficiency and reduce losses of nitrate from fields. A threeyear (2012-2014) field study was conducted to compare the effects of three irrigation scheduling methods: Irrigator Pro (IPRO); normalized difference vegetative index (NDVI) and soil water potentials (SWP) and two levels of nitrogen $(\mathrm{N})$ (157 and $224 \mathrm{~kg} \mathrm{~N} \mathrm{ha}^{-1}$ ) on nitrate level, water-use, and yield of corn grown on four soil types in the Coastal Plains, USA. Yield of corn was not affected by irrigation methods or soil types. Both yield and water-use efficiency (WUE) of corn differed among years. Average yields and WUE were 15.6, 10.5 and $13.5 \mathrm{Mg} \mathrm{ha}^{-1}$ and 29.8, 16.8 and $23.8 \mathrm{~kg}_{\text {grain }} \mathrm{ha}^{-1} \mathrm{~mm}^{-1}$ in 2012, 2013 and 2014, respectively. Leached nitrate varied significantly with irrigation and $\mathrm{N}$ management systems, but not with soil types. The IPRO method had the lowest concentration of nitrate $\left(11.1 \mathrm{mg} \mathrm{L}^{-1}\right)$ followed by SWP $\left(16.5 \mathrm{mg} \mathrm{L}^{-1}\right)$ and NDVI (17.9 $\left.\mathrm{mg} \mathrm{L}^{-1}\right)$. The low $\mathrm{N}$ application rate resulted in a lower nitrate concentration $\left(13.4 \mathrm{mg} \mathrm{L}^{-1}\right)$ than the high $\mathrm{N}$ rate $\left(17.0 \mathrm{mg} \mathrm{L}^{-1}\right)$. Our results suggest that each irrigation method was able to adequately manage irrigation to produce adequate corn yields for the region. Since the IPRO method resulted in a lower nitrate concentration in the lysimeters, the results indicate that a scheduling method may be a way to reduce fertilizer $\mathrm{N}$ losses to leaching on these soils.
\end{abstract}

Keywords: groundwater, nitrate, irrigation, nitrogen, coastal plain, water-use efficiency, NVDI, soil water potentials. 


\section{Introduction}

Different types of soils in southeastern USA have different water holding capacities and hydraulic conductivities and therefore may require different depths and rates of water application to reach field capacity and minimize potential runoff and/or groundwater leaching of nutrients [1]. Irrigation management for corn (Zea mays L.) production in the southeastern region of the USA is difficult because of the highly variable climate along with typical low water holding capacity and low fertility of the soils. These conditions, among others in recent years, have led to have much emphasis on site-specific management for agriculture which includes soil mapping [2], soil nutrient management and assessment [3, 4], yield monitoring [5, 6] and irrigation management using a variable-rate irrigation system [7].

Variable-rate irrigation systems are capable of spatially allocating limited water resources while potentially increasing profits for farmers. Spatial water applications attempt to overcome site-specific problems that include spatial variability in topography, soil types, soil-water availability and landscapes' features [7]. Currently, there are no readily identified decision support systems for site-specific water management. Interest in site-specific irrigation management system has emerged over the past decade in response to successful commercialization of other site-specific application technologies in irrigated agriculture. This interest can be attributed to the desire of improving water use efficiency as well as complement management of other crop inputs such as nitrogen for groundwater protection. Although may still lacking scientific evidence, site-specific irrigation management may likely advantageous in regards to reducing the impact of irrigated agriculture on water resources through improved water use efficiency. Additionally, site-specific irrigation management system has the potential to reduce leaching of nitrogen from the crop root zone, but this has not yet been fully demonstrated in the field. The objective of this study was to evaluate and compare the effects of three irrigation scheduling methods and nitrogen management on nitrate level in shallow groundwater, water-use and yield of corn grown on four soil types in humid Coastal Plains, USA.

\section{Materials and methods}

\subsection{Site description}

From 2012 to 2014, corn (Zea mays) was grown under conservation tillage on a 6-ha site under a variable-rate center pivot irrigation (VRI) system near Florence, South Carolina. Each year, field preparation started with an application of glyphosate to control winter weeds. Field tillage at corn planting consisted of inrow sub-soiling. The corn (Dekalb 66-97 in 2012 and 2013, and Dekalb DKC66-97 in 2014) was planted in $76 \mathrm{~cm}$ rows, with a planting population of 79,000 seeds per hectare. The planting dates for the three years were $3 / 30 / 2012$, $4 / 9 / 2013$, and 4/4/2014. Nitrogen $\left(225 \mathrm{~kg} \mathrm{ha}^{-1}\right)$ was applied through the irrigation 
system in three applications. All nitrogen fertilizer, except pre-plant granular applications, was applied via fertigation. The monthly average rainfall in the study site during the growing season of corn is presented in Figure 1. Soils under the center pivot irrigation system are highly variable. Some of the selected properties of the soils are shown in Table 1. These soils consisting of four soil types are as follows: i) Bonnaeau, BhA; loamy, siliceous, subactive, thermic Arenic Paleudults; ii) Norfolk, NkA; fine loamy, kaolinitic, thermic Typic Kandiudults; iii) Dunbar, Dn; fine loamy, kaolinitic, thermic, Aeric Paleaquults; and iv) Noboco, NcA; fine loamy, siliceous, subactive, thermic Oxyaquic Paleudults (Figure 2).

Table 1: $\quad$ Selected properties of the different soils (BhA, NkA, Dn and NcA) that were used in the study.

\begin{tabular}{|c|c|c|c|c|}
\hline $\begin{array}{l}\text { Soil } \\
\text { Properties }\end{array}$ & $\begin{array}{c}\text { Bonneau } \\
\text { soil (BhA) }\end{array}$ & $\begin{array}{c}\text { Norfolk } \\
\text { soil (NkA) }\end{array}$ & $\begin{array}{l}\text { Dunbar } \\
\text { soil (Dn) }\end{array}$ & $\begin{array}{l}\text { Noboco soil } \\
\qquad(\mathrm{NcA})\end{array}$ \\
\hline \multicolumn{5}{|l|}{ Physical properties } \\
\hline Sand $\left(\mathrm{g} \mathrm{kg}^{-1}\right)$ & 710 & 807 & 674 & 755 \\
\hline Silt $\left(\mathrm{g} \mathrm{kg}^{-1}\right)$ & 190 & 167 & 257 & 180 \\
\hline Clay $\left(\mathrm{g} \mathrm{kg}^{-1}\right)$ & 100 & 26 & 69 & 85 \\
\hline Texture & $\begin{array}{l}\text { Loamy } \\
\text { sand }\end{array}$ & $\begin{array}{l}\text { Loamy } \\
\text { sand }\end{array}$ & $\begin{array}{l}\text { Loamy } \\
\text { fine sand }\end{array}$ & $\begin{array}{l}\text { Loamy } \\
\text { sand }\end{array}$ \\
\hline \multicolumn{5}{|l|}{ Chemical properties } \\
\hline $\mathrm{pH}$ & 5.51 & 5.25 & 5.19 & 4.55 \\
\hline $\mathrm{C}\left(\mathrm{g} \mathrm{kg}^{-1}\right)$ & 7.2 & 5.8 & 13.8 & 8.3 \\
\hline $\mathrm{N}\left(\mathrm{g} \mathrm{kg}^{-1}\right)$ & 0.5 & 0.8 & 0.1 & 0.6 \\
\hline $\mathrm{P}\left(\mathrm{mg} \mathrm{kg}{ }^{-1}\right)$ & 50.9 & 20.3 & 95.4 & 39.6 \\
\hline $\mathrm{K}\left(\mathrm{mg} \mathrm{kg}^{-1}\right)$ & 53.9 & 121.5 & 168.3 & 77.3 \\
\hline $\mathrm{Ca}\left(\mathrm{mg} \mathrm{kg}^{-1}\right)$ & 247.6 & 244.5 & 419.4 & 484.9 \\
\hline $\operatorname{Mg}\left(\mathrm{mg} \mathrm{kg}^{-1}\right)$ & 55.6 & 54.7 & 113.2 & 74.1 \\
\hline $\mathrm{Na}\left(\mathrm{mg} \mathrm{kg}^{-1}\right)$ & 37.1 & 29.6 & 34.8 & 35.9 \\
\hline $\mathrm{Al}\left(\mathrm{mg} \mathrm{kg}^{-1}\right)$ & 687.3 & 924.7 & 1062.7 & 924.4 \\
\hline $\mathrm{Fe}\left(\mathrm{mg} \mathrm{kg}^{-1}\right)$ & 25.1 & 10.7 & 23.6 & 21.6 \\
\hline $\mathrm{Cu}\left(\mathrm{mg} \mathrm{kg}^{-1}\right)$ & 0.3 & 0.2 & 0.2 & 0.6 \\
\hline $\mathrm{Zn}\left(\mathrm{mg} \mathrm{kg}^{-1}\right)$ & 4.8 & 3.8 & 3.5 & 4.1 \\
\hline
\end{tabular}

Bonneau soil - loamy, siliceous, subactive, thermic Arenic Paleudults; 0 to $2 \%$ Norfolk soil - fine loamy, kaolinitic, thermic Typic Kandiudults; 0 to $2 \%$ Dunbar soil - fine loamy, kaolinitic, thermic, Aeric Paleaquults; 0 to $1 \%$ Noboco soil - fine loamy, siliceous, subactive, thermic Oxyaquic Paleudults; 0 to $2 \%$. 


\subsection{Irrigation management}

Three irrigation treatments were evaluated for our study. The first irrigation treatment was based on the Irrigator Pro for Corn expert system (IP) that was developed by the USDA-ARS-National Peanut Research Laboratory, Dawson, GA. This expert system has been tested extensively in uniformly irrigated fields [8-11]. In this research, Irrigator Pro for corn was implemented using spatial management zones corresponding to variable soil types. Irrigator Pro uses soil texture and soil water potential measurements to estimate the soil water holding capacity in the root zone for water balance calculations.

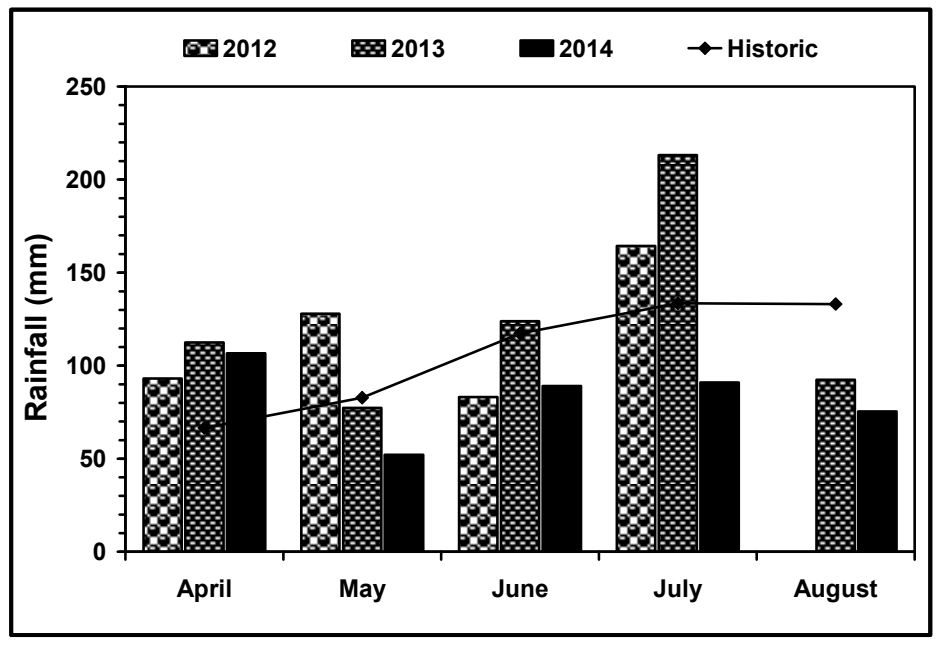

Figure 1: Average monthly rainfall distribution in the study site during the growing season of corn.

The second irrigation treatment (soil water potential (SWP) treatment) was based on using soil water potential sensors to maintain soil water potentials (SWP) above $-30 \mathrm{kPa}$ (approximately 50\% depletion of available water) in the surface $30 \mathrm{~cm}$ of soils within a plot. Soil water potentials were measured from 12 sites within each soil type. In each treatment and replication, tensiometers (Soilmoisture Equipment Corp,, Santa Barbara, CA) were installed in the individual soil types within each plot at two depths $(0.30$ and $0.60 \mathrm{~m})$. Measurements were recorded at least three times each week. The $0.30-\mathrm{m}$ tensiometer in the SWP treatment was used to initiate irrigation applications. When the soil water potential of the SWP treatments decreased below $-30 \mathrm{kPa}$, a 12.5-mm irrigation application was applied to that plot. Additionally, if soil water potentials decreased below $-50 \mathrm{kPa}$, an additional $12.5 \mathrm{~mm}$ of irrigation was applied if the rainfall forecast was less than $50 \%$.

The third treatment was based on remotely sensing the crop normalized difference vegetative index (NDVI treatment). The NDVI treatment was used to estimate crop coefficients using methods similar to those used by Bausch [12] 
and Glenn et al. [13]. These estimated crop coefficients will then be used in the FAO 56 duel crop coefficient method for estimating crop evapotranspiration $\left(E T_{c}\right)$ and irrigation requirements. Initially in 2012, the crop coefficients were based on the FAO 56 crop coefficients for field corn $\left(\mathrm{K}_{\mathrm{cb} \text { ini }}=0.15, \mathrm{~K}_{\mathrm{cb} \text { mid }}=1.15\right.$, and $\left.\mathrm{K}_{\mathrm{cb} \text { end }}=0.5\right)$. After crop establishment and NDVI measurements were collected, the crop coefficients were updated and estimated using the soil adjusted vegetative index (SAVI). The SAVI values were shown to be nearly linearly related to ET (Glenn et al. [13]). The NDVI measurements were collected throughout the growing season until tasseling using a Crop Circle ACS-430 active crop canopy sensor and GeoSCOUT GLS-400 data logger (Holland Scientific, Inc., Lincoln, NE). The mean NDVI and SAVI values were calculated from the collected reflectance measurements and the SAVI values were utilized for the crop coefficients $[12,13]$.

Additional information on the three irrigation scheduling method can be found in a recent paper published by Stone et al. [14].

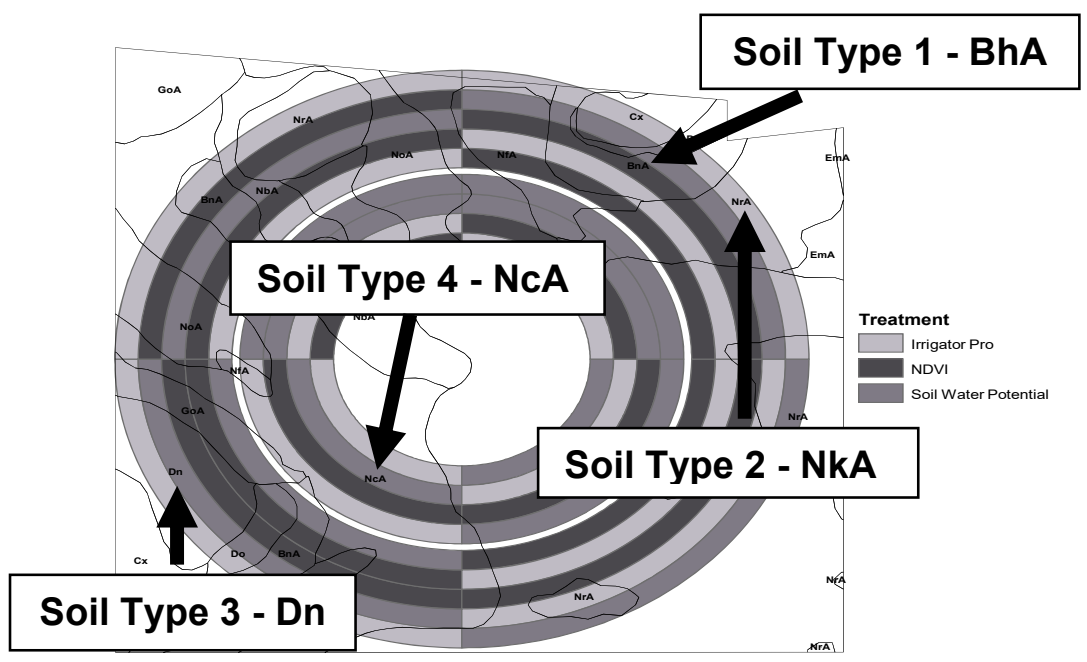

Figure 2: Plot map showing the different soil types for the irrigation study.

\subsection{Instrumentation, water sample collection and sample analyses}

Each soil type was instrumented with six pairs of Soil Moisture Suction Lysimeters (Model 1900) consisted of two depths $(31 \mathrm{~cm}$ and $91 \mathrm{~cm})$. With the use of a 10.2-cm auger, the site was cored to a depth of $46 \mathrm{~cm}$ and $107 \mathrm{~cm}$, respectively. The soil from the hole was sifted through a $0.6 \mathrm{~cm}$ mesh screen to free it of pebbles and rocks to provide a reasonably uniform backfill soil for filling around the suction lysimeters. The Soil Moisture Suction lysimeters was inserted to the hole. Bentonite clay was used to backfill the soil surface followed by silica sand layer of about $15.2 \mathrm{~cm}$. The rest of the hole was backfilled slowly 
with the screened native soil, free of pebbles and rocks accompanied by tamping continuously with a metal rod around the hole to prevent surface water from channelling down between the soil and the body of the sampler. To collect water samples, the clamping ring on the stopper was removed. The tube fitting on the end of the vacuum hand pump was inserted into the neoprene tube of the stopper assembly. The vacuum within the sampler caused the moisture to move from the soil through the porous ceramic cup and into the sampler. Water sample from the sampler was collected using a flask with two-hole rubber stopper. One hole was directly connected to the plastic tubing from the sampler and one hole was connected to the hand vacuum pump. Stroking the hand pump created vacuum within the flask which in turn sucks the sample up from the sampler and into the collection bottle. Suction lysimeters were completely evacuated one day before and during the sampling process to ensure that the water samples would be fresh and acceptable.

Water samples were transported to the laboratory following collection and refrigerated at $4^{\circ} \mathrm{C}$. Water samples were filtered using a $0.2 \mu$ m nylon filter and were analyzed for soluble nitrate $\left(\mathrm{NO}_{3}\right)$ by Ion Chromatography (IC) (Dionex IC-2000, Dionex Corp., USA).

\subsection{Data reduction and statistical analysis}

Concentrations of nitrate in shallow groundwater, water use efficiency and corn yield were analyzed following the principles of a three-way ANOVA using PROC GLM (SAS, 2000). The model included irrigation type (IT), nitrogen management (NM) and soil types (ST). Where the F-test indicated a significant $(\mathrm{p} \leq 0.05)$ treatment effects, means were separated following the method of Least Significant Difference (LSD) and/or Duncan Multiple Range Test (DMRT) using appropriate error mean squares [15].

\section{Results and discussion}

\subsection{Nitrate leaching}

Nitrate leaching varied significantly $(\mathrm{p} \leq 0.001)$ with the interactions of ST x NM $\mathrm{x}$ IT and ST $\mathrm{x}$ IT (Table 3). The highest concentration of nitrate leached (42.3 $\mathrm{mg} \mathrm{L}^{-1}$ ) was from the Noboco soil (NcA) that was fertilized with $224 \mathrm{~kg} \mathrm{~N} \mathrm{ha}^{-1}$ under the SWP irrigation scheduling method while the least amount of nitrate leached of about $7.6 \mathrm{mg} \mathrm{L}^{-1}$ was from the IPRO system in Dunbar soil (Dn) with $224 \mathrm{~kg} \mathrm{~N} \mathrm{ha}^{-1}$ (Figure 3).

The different irrigation scheduling methods had significantly affected the amount of nitrate leached (Table 2). The concentration of nitrate in the shallow groundwater under different irrigation scheduling when averaged across soil types and nitrogen management were as follows: NDVI $\left(17.9 \mathrm{mg} \mathrm{L}^{-1}\right)>\mathrm{SWP}$ $\left(16.5 \mathrm{mg} \mathrm{L}^{-1}\right)>$ Irrigator PRO $\left(11.1 \mathrm{mg} \mathrm{L}^{-1}\right)$. Table 3 presents additional statistical parameters on the concentration of nitrate leaching among the different irrigation method scheduling. It could be well noted that the median amount 
nitrate leached (averaged in three years) among the different irrigation scheduling was at or below the $10 \mathrm{mg} \mathrm{L}^{-1}$ nitrate threshold in drinking water [16]. The median concentration of nitrate leached from system with IPRO was about $6.77 \mathrm{mg} \mathrm{L}^{-1}$ followed by SWP $\left(9.1 \mathrm{mg} \mathrm{L}^{-1}\right)$ and NDVI $\left(10.3 \mathrm{mg} \mathrm{L}^{-1}\right)$. The use of IPRO reduced the amount of nitrate leached by about $39 \%$ and $33 \%$ when compared with NDVI and SWP, respectively. Irrigator PRO may have some advantages in terms of minimizing the amount of nitrate being leached during irrigation when compared with NDVI and SWP. Irrigator PRO can assist producers with irrigation management more effectively than NDVI and SWP by integrating several factors including soil types, yield potential, cultivars and planting date. It has the capability of recommending a decision on when and how much to irrigate during growing season. The built-in expert system in irrigation PRO capable of analyzing rainfall data, soil water potentials and percent chance of rain, among others could be useful in improving nutrient management and minimizing potential losses of nutrients via leaching during irrigation.

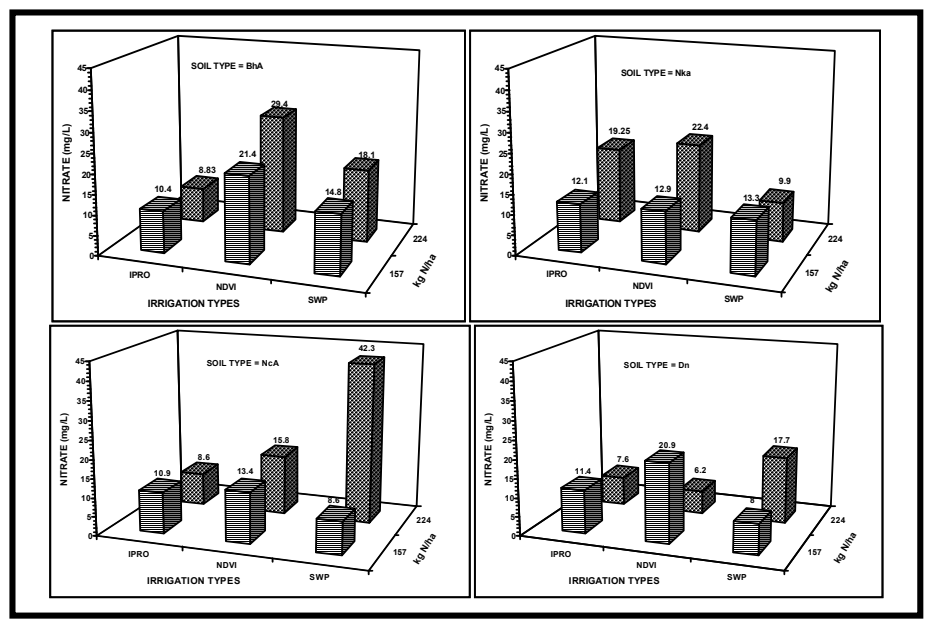

Figure 3: Concentrations of nitrate leached from the different soil types applied with nitrogen under the different irrigation scheduling methods.

The amount of nitrate leached in the shallow groundwater was not significantly affected by soil types (Table 2). Numerically, the amount of nitrate leached among the different soil types in descending order were as follows: $\mathrm{BhA}$ $\left(17.2 \mathrm{mg} \mathrm{L}^{-1}\right)>\operatorname{Dn}\left(16.5 \mathrm{mg} \mathrm{L}^{-1}\right)>\mathrm{NcA}\left(14.8 \mathrm{mg} \mathrm{L}^{-1}\right)>\mathrm{NkA}\left(12.2 \mathrm{mg} \mathrm{L}^{-1}\right)$.

The average concentration of nitrate in the shallow groundwater varied significantly with nitrogen management $(\mathrm{p} \leq 0.05)$. Application of $224 \mathrm{~kg} \mathrm{~N} \mathrm{ha}^{-1}$ (17.0 $\mathrm{mg} \mathrm{L}^{-1}$ ) yielded greater concentration of nitrate leached when compared with the application of $157 \mathrm{~kg} \mathrm{~N} \mathrm{ha}^{-1}$ with mean concentration of about $13.4 \mathrm{mg} \mathrm{L}^{-1}$ (Table 2). 
Table 2: Nitrate leached, yield of corn and water use efficiency of corn as affected by different irrigation scheduling methods, nitrogen management and soil types.

\begin{tabular}{|c|c|c|c|}
\hline Treatments & $\begin{array}{c}\mathrm{NO}_{3} \\
\left(\mathrm{mg} \mathrm{L}^{-1}\right)\end{array}$ & $\begin{array}{c}\text { Yield } \\
\left(\mathrm{Mg} \mathrm{ha}^{-1}\right)\end{array}$ & $\begin{array}{c}\text { WUE } \\
\left(\mathrm{kg} \mathrm{grain} \mathrm{ha}^{-1} \mathrm{~mm}^{-1}\right)\end{array}$ \\
\hline \multicolumn{4}{|l|}{ A. Irrigation type } \\
\hline 1. Irrigator $\mathrm{PRO}$ & $11.1 \mathrm{~b}^{\dagger}$ & $13.4 \mathrm{a}$ & $23.3 \mathrm{a}$ \\
\hline 2. NDVI & $17.9 \mathrm{a}$ & $13.3 \mathrm{a}$ & $23.7 \mathrm{a}$ \\
\hline 3. SWP & $16.5 \mathrm{a}$ & $12.9 \mathrm{a}$ & $23.4 \mathrm{a}$ \\
\hline \multicolumn{4}{|l|}{ B. Nitrogen } \\
\hline 1. $\quad 157 \mathrm{~kg} \mathrm{~N} \mathrm{ha}^{-1}$ & $13.4 \mathrm{~b}$ & - & - \\
\hline 2. $224 \mathrm{~kg} \mathrm{~N} \mathrm{ha}^{-1}$ & $17.0 \mathrm{a}$ & - & - \\
\hline \multicolumn{4}{|l|}{ C. Soil type } \\
\hline 1. $\mathrm{BhA}$ & $17.2 \mathrm{a}$ & $12.9 \mathrm{a}$ & $23.0 \mathrm{ab}$ \\
\hline 2. $\mathrm{NkA}$ & $12.2 \mathrm{a}$ & $13.2 \mathrm{a}$ & 23.6ab \\
\hline 3. Dn & $16.5 \mathrm{a}$ & $12.9 \mathrm{a}$ & $22.6 b$ \\
\hline 4. $\mathrm{NcA}$ & $14.8 \mathrm{a}$ & $13.7 \mathrm{a}$ & $24.5 \mathrm{a}$ \\
\hline \multicolumn{4}{|l|}{ Sources of variation } \\
\hline Soil Type (ST) & $\mathrm{ns}^{+}$ & ns & $*$ \\
\hline Nitrogen Mgt (NM) & * & - & - \\
\hline Irrigation Type (IT) & $* *$ & ns & ns \\
\hline ST x IT & $* *$ & ns & ns \\
\hline ST x NM x IT & $* *$ & - & - \\
\hline
\end{tabular}

$\uparrow$ Means followed by the same letter(s) under each column and sub-heading are not significantly different from each other at $\mathrm{p} \leq 0.05$.

${ }^{*} \mathrm{~ns}-$ not significant; * - significant at $\mathrm{p} \leq 0.05 ; * *$ - significant at $\mathrm{p} \leq 0.01$; $* * *$ - significant at $\mathrm{p} \leq 0.001$

BhA - Bonneau loamy fine sand; NkA - Norfolk loamy fine sand; Dn - Dunbar loamy fine sand; NcA - Noboco loamy fine sand.

\subsection{Corn yield}

The average corn yields for the three-year study across the three irrigation treatments ranged from 12.9 to $13.4 \mathrm{Mg} \mathrm{ha}^{-1}$. The three-year mean corn yield for the three irrigation treatments was not significantly different from each other (Table 2). The three-year mean corn yield did not vary significantly among the four soil types. The average corn yield among the different soil types are as follows: NcA (13.7 $\left.\mathrm{Mg} \mathrm{ha}^{-1}\right)>\mathrm{NkA}\left(13.2 \mathrm{Mg} \mathrm{ha}^{-1}\right)>\mathrm{BhA}\left(12.9 \mathrm{Mg} \mathrm{ha}^{-1}\right)=\mathrm{Dn}$ (12.9 $\left.\mathrm{Mg} \mathrm{ha}^{-1}\right)$.

For the three-year study, we have evaluated the overall and inter-annual homogeneity of variance of corn yield to determine if there were greater variances in yield among the different soil types. In 2012 and 2014, there were no significant variances between soil types. However, in 2013, we have observed slight-by-significant differences in variances of corn yield among soil types. Similar variability in corn yield was observed by Sadler et al. [17] and Karlen et 
al. [5]. Based on our three-year study, with different rainfall distribution throughout the growing season (Figure 1), our results have shown that each of the three irrigation scheduling methods may be able to provide the adequate amount of irrigation water to produce good to excellent corn yields for the region.

Table 3: $\quad$ Summary statistics for the average concentration of nitrate leached from a corn production under different irrigation scheduling methods.

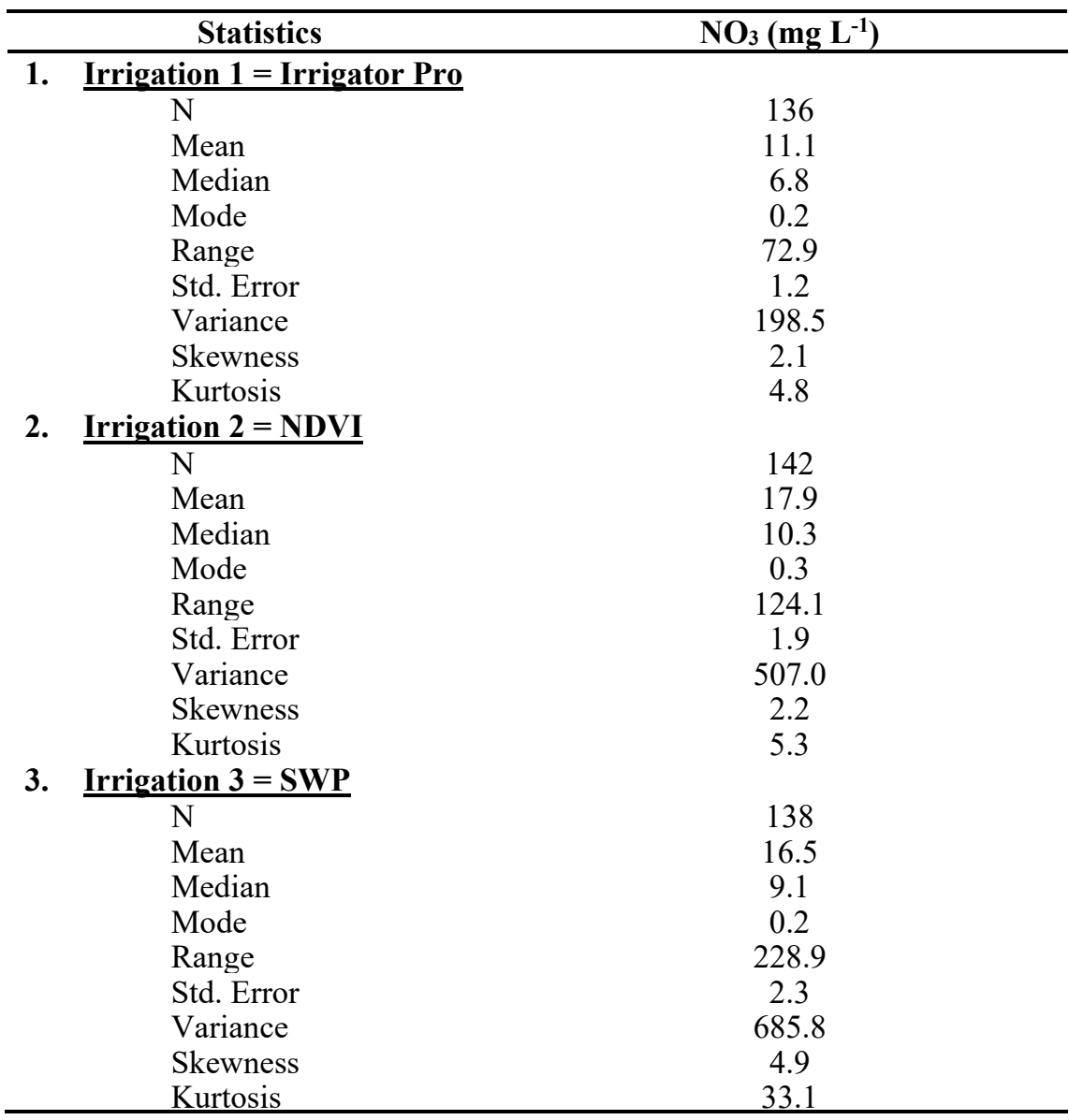

\subsection{Water-use efficiency (WUE)}

The overall three-year WUE of corn was not significantly different among the three irrigation scheduling method. However, the soil type $(\mathrm{p} \leq 0.05)$ was significantly different in the overall analysis (Table 2). The average WUE 
( $\mathrm{kg}$ grain $\mathrm{ha}^{-1} \mathrm{~mm}^{-1}$ ) were 23.3, 23.7 and 23.4 for IPRO, NDVI and SWP, respectively.

On the effect of soil types, NcA had the greatest WUE of $24.5 \mathrm{~kg}$ grain $\mathrm{ha}^{-1}$ $\mathrm{mm}^{-1}$ followed by NkA (23.6 kg grain ha $\left.\mathrm{mm}^{-1}\right)$, BhA $\left(23.0 \mathrm{~kg}\right.$ grain ha $\mathrm{mm}^{-1}$ ) and Dn $\left(22.6 \mathrm{~kg}_{\text {grain }} \mathrm{ha}^{-1} \mathrm{~mm}^{-1}\right)$.

Although our results may not show differences in WUEs among the three types of irrigation scheduling method, the WUE values that we observed from our study were similar to corn WUE values that were previously reported (Table 2). In eastern Colorado, Benjamin et al. [18] reported irrigated WUE values ranging from 10.0 to $22.0 \mathrm{~kg}_{\text {grain }} \mathrm{ha}^{-1} \mathrm{~mm}^{-1}$. Kiniry et al. [19] reported WUE values ranging from 14 to $25 \mathrm{~kg}$ grain $\mathrm{ha}^{-1} \mathrm{~mm}^{-1}$ in regional simulation studies. Sadras et al. [20] reported a much higher WUE values ranging from 27.0 to $37.0 \mathrm{~kg}$ grain $\mathrm{ha}^{-1} \mathrm{~mm}^{-1}$ in more intensely managed field using center pivots. Again, results of our WUE analysis were consistent across the three types of irrigation scheduling method, suggesting that each irrigation method was able to adequately provide the needed irrigation to produce adequate corn yield for the region.

\section{Summary and conclusions}

A three-year (2012-2014) field study was conducted to compare the effects of three irrigation scheduling methods (IPRO, NDVI and SWP) and two levels of N (157 and $224 \mathrm{~kg} \mathrm{~N} \mathrm{ha}^{-1}$ ) on nitrate level in shallow groundwater, water-use, and yield of corn grown on four soil types in the Coastal Plains, USA. Based on our three-year study, with different rainfall distribution throughout the growing season, our results have shown that each of the three irrigation scheduling method may be able to provide the adequate amount of irrigation water to produce good-to-excellent corn yields for the region.

The use of IPRO reduced the amount of nitrate leached by about $39 \%$ and $33 \%$ when compared with NDVI and SWP, respectively. Irrigator PRO may have some advantages in terms of minimizing the amount of nitrate being leached during irrigation when compared with NDVI and SWP. Irrigator PRO has the lowest amount of nitrate being leached into the shallow groundwater beneath corn production. Based on the concentration of nitrate being leached into the shallow groundwater that we observed in our study, the amount of leached nitrate associated with the different irrigation scheduling method were greater than $10 \mathrm{mg}$ nitrate $\mathrm{L}^{-1}$. This level of nitrate being leached could pose a harmful effect on the environment and therefore would require a continued and long-term monitoring and assessment. There is a need to further understand the different landscape locations and varying hydrologic conditions because it can affect the spatial and temporal variations of nitrate losses at the watershed scale. If we can understand where and how nitrate is getting into our shallow groundwater, we can implement best management practice to reduce or even eliminate nitrate as potential pollutant from our water supply. Since the IPRO method resulted in lower nitrate concentration in the shallow groundwater, the results indicate 
scheduling method may be a way to reduce fertilizer $\mathrm{N}$ losses to leaching on these soils.

\section{References}

[1] Omary, M., Camp, C.R. \& Sadler, E.J. Center pivot irrigation system modification to provide variable water application depths. Applied Engineering Agriculture, 13(2), pp. 235-239, 1996.

[2] Muhr, T., Auernhammer, H., Demner, M., Wild, \& K. Inventory of fields and soils with DGPS and GIS for precision farming. ASAE Paper No. 941583. St. Joseph, Mich. ASAE. 1994.

[3] Hanns D., \& Breadmaker, J.D. Soil nutrient mapping implication using GPS. Computer and Electronics in Agric. 11(1), pp. 37-51, 1994.

[4] Zhang, B., Zhang, N., Schrock, M.D., Havlin, J.L. \& Kluitenberg. Development of a field-scale GIS database for spatially variable nitrogen management. ASAE Paper No. 94-3550. St. Joseph, Mich.: ASAE. 1994.

[5] Karlen, D.L., Sadler, E.J., \& Busscher, W.J. Crop yield variation associated with Coastal Plain soil map units. Soil Sci. Soc. Amer. J. 54, pp. 859-865, 1990.

[6] Sadler, E.J., Camp, C.R., \& Busscher, W.J. emitter flow rate changes caused by excavating subsurface micro-irrigation tubing. In Proc. $5^{\text {th }}$ Int. Micro-irrigation Cong. 763-768. St. Joseph, Mich. ASAE. 1995.

[7] Stone, K.C., Bauer, P.J., Busscher, W.J., Millen, J.A., Evans, D.E. \& Strickland, E.E. Variable-rate irrigation management using an expert system in the eastern coastal plain. Irrig. Sci. 33, pp. 167-175, 2015.

[8] Davidson, J.I. Jr., Griffin, W.J., Lamb, M.C., Williams, R.G., \& Sullivan, G. Validation of EXNUT for scheduling peanut irrigation in North Carolina. Peanut Sci. 25, pp. 50-58, 1998.

[9] Davidson, J.I., Jr., Bennett, C.T., Tyson, T.W., Baldwin, J.A., Beasley, J.P., Bader, M.J., \& Tyson, A.W. Peanut irrigation management using EXNUT and MOISNUT computer programs. Peanut Sci. 25(2), pp. 103$110,1998$.

[10] Lamb, M.C., Masters, M.H., Rowland, D., Sorensen, R.B., Zhu, H., Blankenship, R.D., \& Butts, C.L. Impact of sprinkler irrigation amount and rotation on peanut yield. Peanut Sci. 31(2), pp. 108-113, 2004.

[11] Lamb, M.C., Rowland, D.L., Sorensen, R.B., Butts, R.B., Faircloth, C.L., \& Nutt, R.C. Economic returns of irrigated and non-irrigated peanut based cropping systems. Peanut Sci. 34, pp. 10-16, 2007.

[12] Bausch, W.C. Soil background effects on the reflectance-based coefficients for corn. Remote Sens. Environ, 46, pp. 213-222, 1993.

[13] Glenn, E.P., Neale, C.M.U., Hunsaker, D.J., \& Nagler, P.L. Vegetation index-based crop coefficients to estimate evapotranspiration by remote sensing in agricultural and natural ecosystems. Hydrological Processes, 25, pp. 4050-4062, 2011. 
[14] Stone, K.C., Bauer, P.J. \& Sigua, G.C. Irrigation management using an expert system, soil water potentials and vegetative indices for spatial applications. St. Joseph, Mich. ASAE. 2016 (Accepted).

[15] SAS Institute. SAS/STAT User's Guide. Release 6.03. SAS Institute. Cary, NC.

[16] Sigua, G. C., Hubbard, R. \& Coleman, S.W. Nitrogen in soils, plants and shallow groundwater beneath a bahiagrass-based pasture with cow-calf operations. Nutrient Cycling in Agroecosystems Journal. DOI 10.1007/s10705-009-9281-8, 2009.

[17] Sadler, E.J., Busscher, W.J., Bauer, P.J., \& Karlen, D.L. Spatial scale requirements for precision farming: A case study in the southeastern USA. Agron. J. 90(2), pp. 191-197, 1998.

[18] Benjamin, J.G., Nielsen, D.C., Vigil, M.F., Mikha, M.M., \& Calderon, F. Cumulative deficit irrigation effects on corn biomass and grain yield under two tillage systems. Agricultural Water Management, 159, pp. 107-114, 2015.

[19] Kiniry, J.R., Lynd, L. Greene, N., Johnson, M.V., Casler, M. \& Laser, M.S. Biofuels and water use: comparison of maize and switchgrass and general perspectives, Chapter 2. pp. 17-130. In Wright, J.H. and Evans, D.A. (eds.) New Research in Biofuels. Nova Science Publishers. 2008.

[20] Sadras, V.O. Grassini, P., \& Steduto, P. Status of water use efficiency of main crops. SOLAW Background Thematic Report. TR07, Food and Agriculture Organization of the United Nations, 2012. 